\title{
International transport corridors and transborder movement of fictitious capital
}

\author{
Daria Dinets ${ }^{1, *}$, and Albert Dzhavrshian ${ }^{1}$ \\ ${ }^{1}$ Irkutsk State Transport University, ul. Chernyshevskogo, 15, 664074, Irkutsk, Russia
}

\begin{abstract}
The paper is devoted to the analysis of the peculiarities of international transport corridors as a provider of ideas and instruments of liberalization aimed at assigning transport infrastructure to transnational corporations under the auspices of the development of integration processes and their transport service. To achieve the goal of the study, the authors analyzed a wide range of theoretical and empirical data illustrating the claims of Western and, most recently, Eastern multinational corporations on the sovereignty of Russian infrastructure industries. If international transport corridors include transit through Russia, then participation in them takes the form of export of transport services. At the same time, if investments in infrastructure development are foreign, then the type of income for such operations can be considered as a land rent, since the benefits depend only on the ownership of large or small land plots. The article shows the logical transition from this conclusion to the conclusion about the formation of fictitious capital of Russian infrastructure industries as a result of their inclusion in the activities of international transport corridors. The second hypothesis, which is need to be proved or disproved, is the negative role of UTLC (United Transport and Logistics Company) in achieving rational and fair management of container transportations within the framework of the Eurasian Economic Union (EAEU). Summarizing the two lines of the study, the authors concluded that there are risks for national capital and qualitative indicators of the development of infrastructure industries as a result of the active development of international transport corridors.
\end{abstract}

\section{Introduction}

The development of international transport corridors is complicated by the fact that the technical equipment and regulatory restrictions of border and joint areas between different modes of transport determine the time of passage of goods along the transport corridor much more than the main speed.

The OSJD (Organization for Cooperation of Railways) international transport corridors, the transport corridors Europe - Western China and Western Europe - Western China, the sea transport corridors Primorye-1 and Primorye-2, and the corridors of the Northern and partially Central branches of the Silk Road Economic Belt pass through Russia in the West - East direction. In the North-South direction, the transport corridors connect ports of the

\footnotetext{
*Corresponding author: dinets_d_a@mail.ru
} 
Baltic Sea and the Caspian (the Baltic-Volga-Caspian transport corridor), and in addition, a communication is being established between the routes of the Northern Sea Route, the Caspian and Black Seas.

In modern conditions, the international transport corridor is becoming one of the tools for trans-regionalization - a new form of junction of states. If the goal of globalization was to strengthen the trends in the international division of labor and the spheres of attraction of finance and trade, then trans-regionalization manifests itself in the aspiration to form common economic spaces around the centers of world trade and finance.

The change in the principles of subordination in trade and financial relations is caused by the growing influence of overproduction crises in countries and associations that claim to be the world financial centers. Against the backdrop of a global contraction of demand, the international division of labor becomes an unaffordable luxury, and the global finance circulation model drastically changes - trade and economic unions are aimed at forming markets for goods, works and services produced in countries proclaimed as the world financial centers.

In other words, the object of management is not the supply and the level of costs, but the possibility of generating the demand for products and services offered by the leading countries of world trade. And in this context, two practical aspects of forming common markets with participation of Russia are important:

1) the common market assumes the presence of a larger number of buyers than sellers on it. Currently developed models of common markets include mainly sellers of commodities and transport services. Such a model is not viable; the level of costs for competition in such a market will exceed all the possible benefits from the merger;

2) while the most important players have focused their efforts on demand management, it seems that it is necessary to find reserves for managing costs. Only economic efficiency will allow counteracting global changes in the movement of value chains. In other words, if the directions of the movement of value added are determined by the trends in the development of trans-regional groupings, then it is necessary to manage the level of value added in export positions through internal measures.

Moreover, time itself presents unlimited opportunities for the development of the Russian economy: unlike the trade and economic leaders of the West and the East, Russia has no crisis of overproduction or overaccumulation of capital. Under such conditions, supply management can become a key to the growth of competitive advantages at the initial stages of the development of a new technological order.

The growth of export of transport services due to involvement in international transport corridors is complicated by the presence of geopolitical contradictions between Russia and the trans-regional blocs located in the East (Regional Comprehensive Economic Partnership) and the West (Transatlantic Trade and Investment Partnership). The situation is complicated by the fact that there are serious political disputes between these blocs, complicated by the realization that direct trade wars for European markets between the West and the East will lead to the ruin of transnational corporations, which is contrary to the interests of all participants in international trade.

In these conditions, the search for compromises in the direction of trade and financial flows becomes the only possible strategy for all parties involved in the process of redistribution of power in international trade.

It is worth mentioning the following main geopolitical contradictions between Russia and TTIP:

1) the aspiration of the North American countries to expand the export of shale oil and LNG to Europe and drive out Russia from the respective markets;

2) the formation of gas hubs in Europe, the priority of hub pricing with the establishment of prices "here and now" depending on the level of supply and demand for 
the relevant resources, the refusal to conclude long-term contracts linked to the prices of the oil basket;

3) the formation of free access for all market participants to the gas transportation and transmission network infrastructure, the requirement to transfer gas transportation infrastructure and transmission capacity to independent operators (transmission system operators).

As for the contradictions between Russia and the countries belonging to the RCEP (Regional Comprehensive Economic Partnership), the eastern countries, which are affected by the crisis of overproduction, implement investment projects that provide the infrastructure for trade in their goods and strive to maintain control over this infrastructure. As a payment for the implementation of investment projects for the development of international transport corridors, preferential treatment and (or) stake in ownership of the energy resources produced in Russia are established.

Among other things, Asian hub projects are also implementing to promote Chinese goods with lower costs due to economies of scale. It seems that to achieve these goals, development of the following hubs are planned by the Chinese side and in the framework of the OBOR initiative:

1) Singapore, South Korea - trade with the Pacific Rim,

2) Kazakhstan - trade with the Caspian countries, the countries of the Persian Gulf, Pakistan, India, the countries of South America,

3) Iceland - trade with European and North American countries.

Such a regime of investment interaction threatens national sovereignty and contributes to the stagnation of the Russian economy. Moreover, the investment resources received by the country in this regime lead to the fact that transport becomes a rental industry and falls out of the system of expanded reproduction of social capital, involving in the circulation of financial capital, which, without the possibility of reinvestment, becomes fictitious capital.

The formation of rent in the transport industry means that the Russian side receives its revenues only from the fact that it carries out transport construction for the transportation of goods by the country that finances the project. In other words, the economic content of such relations is reduced to receiving rent from the provision of land lease services. Further, since the infrastructure built without the export of transport services to Asian partners is excessive, there is no possibility of reinvesting the received rent, therefore, there are high chances that these funds will be channeled to the financial markets where another financial bubble is being formed. The situation is complicated by the fact that many calculations are still carried out in dollars, i.e. dependence on the US economy manifests itself even in operations with eastern partners.

Therefore, we believe that the current model of attracting Chinese investments is an additional source of risk of losing sovereignty over the objects of transport infrastructure and intensifying the withdrawal of capital. If transport construction is carried out with the purpose of involving in the international transport corridor, then the approach to project assessment should differ from the assessment of strictly infrastructural projects, i.e. transport construction should be repaid by increasing the volume of export of transport services, without taking into account GDP multipliers, social effects and etc. If the project is not repayable, then its implementation will lead to the withdrawal of capital.

In this context, we also approach the need to manage the supply, cost structure and economic efficiency as the only way to preserve the sovereignty of value added in spite of global trends of its redistribution with the help of international transport corridors and energy platforms.

The preliminary conclusion is that the United States and China are creating markets for their goods and capitals through the implementation of projects for the construction of international transport corridors and energy platforms. And neocolonialism can clearly be 
traced in attempts to control markets, despite the fact that they are based on different instruments. There is also an obvious similarity - the architecture of the offshore Yuan market is very close to the Eurodollar market architecture. In both cases, these are instruments for repatriating the liquidity of investment projects. The level of domestic value added in US exports is steadily falling. Available data for 2014 indicate that the USA is the last one among the OECD countries in terms of the national value added in exports of goods [1]. At the same time, it is proved that the lower the level of national value added in foreign trade, the lower the level of employment in the economy [2]. As for China, the low level of value added in the export of this country was previously perceived as a competitive advantage, whereas today the country is looking for reserves to increase the level of wages, and therefore, the share of value added in exported goods to maintain domestic demand at an acceptable level. The role of hubs and international transport corridors in achieving the goals of expansion of domestic value added in products manufactured in the USA appears to be the possibility of increasing the liquidity of the respective markets with the subsequent transfer of this liquidity to financial markets, including for the export of financial services. That is, if the Chinese model consists in pumping out the rent through financing by it the acquisition of Chinese goods and services, the American one is the transformation of the energy and transport markets into financial ones, on which the unified lots are sold, into which integrated transport solutions traded through hubs are "packaged" (similar to how synthetic mortgage products were once "packaged"). This is caused by the complete unification of transport and logistics services, enabling the trading of certain impersonal conventional units - lots of unified transport and logistics services, regardless of the geography of the movement of goods or the geography of the natural resource extraction. Accordingly, unified lots can be resold unlimited number of times, forming a socalled liquid and competitive market. Summing up the comparison of the western and eastern models of managing international transport corridors, it should be noted that, despite the different instruments, the final objectives are very similar - using the potential and economic resources of other countries to overcome internal crises. In case of China through the establishment of infrastructure dependence and the withdrawal of rents in exchange for Chinese goods, in case of the USA- through the redistribution of liquidity and the expansion of opportunities for speculation in the markets.

The revealed peculiarities of the behavior of key figures determining the development processes of the international transport corridor services market make it possible to formulate conditions that will allow Russia to become an active player in this market, rather than a party receiving land rent because certain transport lines pass through its territory. Such conditions may include:

1. Assessment of the economic efficiency of the implementation of projects focused on the export of transport services. Refusal of all indirect indicators characterizing the efficiency of infrastructure projects. In conditions of involvement in international transport corridors, the project cannot be regarded as strictly infrastructural.

2. Establishment of reinvestment opportunities for profits received from the implementation of the transport construction project. Such an opportunity should be confirmed by the availability of investment tools in projects aimed at increasing the number of redistributions in related technological chains. At the same time, alignment of vertical links is a prerequisite.

3. Engagement of the potential of "North - South" corridors, Indiga port, Sviyazhsky intermodal center, Baltic-Volga-Caspian corridor. Formation of own hubs, which allow obtaining positive scale effect and involving potential buyers in the markets of the Arctic natural resources.

4. Formation of reverse logistical flow within the country and to the East. Wide involvement of BAM in integration processes (Taishet - Komsomolsk-on-Amur). 
5. Using the potential of "North-South" corridors for transporting Arctic energy resources - eliminating seasonal unevenness and diversifying supplies. For example, the European region consumes most of its energy resources in winter, while southern Asian countries consume much of their energy in the summer, when air conditioners are active.

6. Formation of a network of joint energy hubs within a single market, but involving key buyers, presumably, in Kaliningrad, Kazakhstan, Yamal and Vladivostok. Using the high level of uncertainty of changes in hub prices for energy resources in Europe. Introduction of a settlement system based on the unit of account tied to national currencies.

7. Establishment of energy and transport dialogue not only with Eastern countries, but also resolution of disputes in the traditional European markets with the goal of combining efforts against the expansion of American fictitious capital.

As the models of common markets and international transport corridors are actively promoted through the integration of the EAEU into the projects of the Silk Road Economic Belt as a part of the united Eurasia, we consider it necessary to consider the main trends in the development of the EAEU transport corridors. For the development of the international railway transport corridors of the EAEU and the implementation of the project on the formation of a unified transport and logistics system, the "United Transport and Logistics Company" (JSC "UTLC") was established on the basis of the assets of the following railway companies: JSC "Russian Railways", "Belarusian Railways" (SO "BZD”) and JSC National Company "Kazakhstan Temir Zholy" (JSC "NC" KTZ”).

The purpose of this infrastructure project was the creation of an intermodal logistics operator to strengthen the transport connections between the economies of the EAEU member countries, to realize the potential of transit container transportations from the People's Republic of China to the European Union, and to increase the volume of traffic through the single economic space. According to the initial investments, the capital structure of JSC "UTLC" is divided into the following shares: JSC "Russian Railways" 99.84\%, JSC "KTZ" and SO "BZD" - $0.08 \%$ per each one, with the condition of gradual achievement of parity until 2021 by repayment of the difference in the value of the contributed property. But up to now, the partners in the EAEU have not contributed to the capital of JSC "UTLC", which at the moment does not exceed the assets of PJSC "Transcontainer", contributed by JSC "Russian Railways". That is, the company operates on the basis of the assets of JSC "Russian Railways", which has lost the opportunity to receive dividends from PJSC "Transcontainer" and JSC "RZD Logistics" under current conditions. For this reason, the management of JSC "Russian Railways" has developed a new reorganization scheme that was approved by the Federal Antimonopoly Service of Russia (FAS) on December 12, 2017 [3].

Reorganization involves the creation of three additional structures presented in the table 1.

Table 1. Reorganization scheme of JSC "UTLC".

\begin{tabular}{|c|c|c|c|c|}
\hline Indicator & \multicolumn{4}{|c|}{ Structure } \\
\hline Company & JSC "UTLC" & $\begin{array}{l}\text { JSC "UTLC } \\
\text { Eurasian Rail } \\
\text { Alliance" }\end{array}$ & $\begin{array}{l}\text { JSC "UTLC } \\
\text { Logistics" }\end{array}$ & $\begin{array}{l}\text { JSC "UTLC } \\
\text { Finances" }\end{array}$ \\
\hline Assets & $\begin{array}{c}\text { PJSC } \\
\text { "Transcontainer" } \\
(50 \%+1 \text { stock })\end{array}$ & $\begin{array}{l}98,127 \text { million } \\
\text { rubles }\end{array}$ & $\begin{array}{c}\text { JSC "RZD } \\
\text { Logistics" } \\
(100 \%- \\
1 \text { stock })\end{array}$ & $\begin{array}{l}\text { dividends, PJSC } \\
\text { "Transcontainer" } \\
\text { and JSC "RZD } \\
\text { Logistics" }\end{array}$ \\
\hline $\begin{array}{l}\text { Capital } \\
\text { stock } \\
\text { structure }\end{array}$ & $\begin{array}{c}\text { JSC “RZD” } \\
\text { (100\%-1 stock); } \\
\text { JSC "RZD } \\
\text { Logistics" (1 } \\
\text { stock) }\end{array}$ & $\begin{array}{c}\text { JSC “RZD" } \\
\text { (33,33\%); } \\
\text { JSC "NC" KTZ" } \\
\text { (33,33\%); } \\
\text { SO “BZD” } \\
(33,33 \%)\end{array}$ & $\begin{array}{c}\text { JSC "RZD" } \\
\text { (100\%-1 stock); } \\
\text { JSC "UTLC" } \\
\text { (1 stock) }\end{array}$ & $\begin{array}{c}\text { JSC "RZD" } \\
\text { (100\%-1 stock); } \\
\text { JSC "UTLC" } \\
\text { (1 stock) }\end{array}$ \\
\hline
\end{tabular}


In fact, JSC "RZD" withdraws its assets from JSC "UTLC" by creating new subsidiaries and affiliates.

According to the new reorganization scheme, JSC "UTLC Eurasian Rail Alliance" (JSC "UTLC ERA") will operate under the "no assets" model with parity participation of Russia, Kazakhstan and Belarus (33.33\% of shares) and will implement the main production activities of JSC "UTLC" for the operation and development of cargo transit on the territory of the countries participating in the project.

In our opinion, if the restructuring of UTLC does not cause changes in Kazakhstan's policy regarding the formation of the common markets of the EAEU and the corresponding transport corridors, this will mean the timely withdrawal of Russian assets from the project in which Russia was originally assigned as a donor of financial assets and political rents in the world political arena. The company's lack of assets after the merger is generally conforms to the Western liberal model of the transport and logistics company, which is responsible for the organization of goods traffic, but does not have assets for selftransportation of goods. If the transport corridors of the EAEU were aimed only at the redistribution of assets, then the termination of participation in the project was timely for Russia.

In view of this, it seems necessary to form its own model of the general transport services market. In this situation, it is impossible to make an unambiguous conclusion about the acceptability of this or that model of the energy and transport market. Only by the use of the most acceptable elements of different models it is possible to withstand the processes of global capital redistribution by the trans-regional associations of the East and the West.

The neocolonial instincts of the liberal market model cannot be unnoticed. Usually this market is formed around a certain center of attraction of technology and finance, from where the financing of purchases of goods produced in these centers and supplied to common (single) markets takes place. This model was mainly used in the second technological order, of course, with a stronger institutionalization of slavery and the colonial nature of relations. At the present time, the system is used in a veiled form, but the principles have not changed.

The risk for the Russian economy is that transport corridors can become conduits for fictitious capital through a mechanism of trans-regionalization and formation of common markets. If the development of transport infrastructure will be implemented with the use of rental reproduction models, without the possibility of reinvesting in the development of the economy, then transport corridors will only exacerbate the negative effects of the neocolonial nature of relations in modern trade.

\section{References}

1. URL : http://www.oecd.org/investment/USA-trade-investment-statistical-countrynote.pdf

2. Value-Added Exports, U.S. Local Labor Markets: Does China Really Matter?, https://www.wto.org/english/res_e/reser_e/gtdw_e/wkshop17_e/silva_e.pdf

3. URL : http://www.utlc.com/news/reorganizatsiya-utlc 